\title{
Influence of different levels and application method of Diphenylamine on production and quality of flower spike of Symphyotrichum novi- belgii L. cv. white Casablanca
}

\author{
Naglaa M. Mostafa \\ Antoniades Research Branch, Ornamental Plants Research and Landscape Gardening Res. Dept, \\ Hort. Res. inst., ARC, Alexandria, Egypt. \\ Corresponding author email: dr.naglaamoh@gmail.com
}

Received on: 9/11/2020

Accepted on: 28/11/2020

\begin{abstract}
The present study was carried out under field conditions at the Experimental Farm and the laboratory of Antoniades Research Branch, Horticulture Research Institute, A.R.C. Alexandria, Egypt during the two successive seasons of (2017-2018) and (2018-2019). The aim of this work was to study the effects of different application levels of diphenylamine (DPA) at rates of (zero, 50, 100 and $200 \mathrm{ppm}$ ) by two application methods (soil drench and foliar spray) on vegetative growth, flowering characteristics, leaves photosynthetic pigments content and postharvest characteristics of Aster New York plants (Symphyotrichum novi-belgii cv. white casablanca). The plants were treated four times at 30, 60, 90 and 120 days from the final transplanting. The results showed that there was no significant difference between DPA application method or their combinations with its different concentrations in most recorded data. On the other hand, using different concentrations of DPA caused a significant effect on all studied characteristics. The highest plant height, leaf area, number of shoots/plant, leaves dry weight, inflorescence stalk diameter and dry weight, root volume and dry weight and leaves content of chlorophyll a, chlorophyll b and total carbohydrate was obtained after using DPA at $100 \mathrm{ppm}$. Also, this treatment caused the longest vase life, the highest final water uptake and floret opening percentage and the lowest loss of flower fresh weight percentage.
\end{abstract}

KEYWORDS: Aster New York - diphenylamine - soil drench - foliar spray

\section{INTRODUCTION} Symphyotrichum novi-belgii (L) G. L. Nesom (Aster New York) plant is a member of family Asteraceae. This plant is characterized by basal rosette leaves and terminal paniculate inflorescences with attached tinny flowers. (Mohamed 2017). The flower heads have several colors (white, purple, yellow and lavender) and sizes. It is used as a cut flower and garden plant. When many perennials are fading toward the end of the season, New York Aster burst into bloom and deliver an outstanding show of color in the late summer and fall. During the last years, its economic importance has been developed by using it as pot plant (Mørk et.al., 2011).

Antioxidants are substances which can prevent or slow the oxidative damage of cell. When cells use oxygen, they naturally produce free radicals (by-products) which can cause damage. Antioxidants act as "free radical scavengers" and hence prevent and repair damage done by the other free radicals. Antioxidants such as diphenylamine have different biological and physiological roles, which reflect on different physiological processes in plant (Naglaa et al., 2011).

Diphenylamine is an aromatic antioxidant amine, with the structural formula of $\left[\left(\mathrm{C}_{6} \mathrm{H}_{5}\right)_{2} \mathrm{NH}\right]$. It acts as plant growth regulator and fungicide. (Eman and Amira, 2014). It is also, widely used to prevent post-harvest deterioration (storage scald) of apple and pear crops (Mir and Beaudry, 1999). As it has many effects on the treated plants (Cindy et al., 2020). Huelin and Coggiola (1970) demonstrated that postharvest application of DPA increased the total antioxidant content and activity in apples, Lurie et al. (1989) found that postharvest treatment of 'Granny Smith' apples by DPA decrease of oxidative enzymes activity. Purvis and Gegogeine (2003) indicated that DPA reduces plant cell respiration by inhibiting the transport of mitochondrial electrons moreover, Du and Bramlage (1994) found that DPA reduced ethylene production and, consequently, the synthesis and oxidation of $\alpha$ farnesene, with diminished surface scald in 'Cortland' apples.

The aim of the present work is to study the effects of different concentrations and application 
method of diphenylamine on the growth, flowering, postharvest characteristics and some chemical constituents of aster (Symphyotrichum novi-belgii L.) cv. White casablanka.

\section{MATERIALS AND METHODS}

The present study was carried out in the two successive seasons (2017-2018) and (2018-2019) at Experimental Farm and the laboratory of Antoniades Research Branch, Horticulture Research Institute, A.R.C. Alexandria, Egypt.
Seeds of Aster New York were planted in plastic trays, using a mixture of peat moss and sandy soil at the ratio of $1: 1$ by volume on the $14^{\text {th }}$ of October, 2017 in the first season and repeated at the same date in 2018 for the second one. The seedlings were transplanted to plastic pots of $25 \mathrm{~cm}$ diameter using a mixture of sandy and clay soil at the ratio of $1: 1$ by volume on November $14^{\text {th }}, 2017$ and November $16^{\text {th }}, 2018$ (in the first and second seasons, respectively). The chemical analysis of the used medium is presented in Table (1).

Table 1. Chemical analysis of the used mixture soil for the two growing seasons (2018and 2019).

\begin{tabular}{lllllllll}
\hline \multirow{2}{*}{$\mathbf{p H}$} & $\begin{array}{l}\mathbf{E C} \\
\mathbf{d s} / \mathbf{m}\end{array}$ & \multicolumn{2}{l}{ Cations (meq/l) } & \multicolumn{5}{l}{ Anions (meq/l) } \\
\cline { 2 - 9 } & $\mathbf{C a}^{++}$ & $\mathbf{M g}^{++}$ & $\mathbf{N a}^{+}$ & $\mathbf{K}^{+}$ & $\mathbf{H C O}_{3}^{-}$ & $\mathbf{C l}^{-}$ & $\mathbf{S O}_{4^{--}}$ \\
\hline $\mathbf{8 . 1 5}$ & $\mathbf{1 . 7}$ & 1.5 & 0.8 & 1.6 & 0.59 & 1.06 & 1.25 & 0.98 \\
\hline
\end{tabular}

\subsection{Treatments:}

Four DPA concentrations $(0,50,100$ or 200 ppm) were applied by two methods either as soil drench (with $350 \mathrm{ml} /$ plant of each concentration of DPA) or as foliar spray (with hand sprayer until the plants were wet to run off). The plants treated four times at 30, 60, 90 and 120 days from the transplanting.

\subsection{The following data were measured in both of the two growing seasons:}

Vegetative growth: Plant height $(\mathrm{cm})$, number of leaves/plant, leaf area/plant $\left(\mathrm{cm}^{2}\right)$ (according to Zidan, 1962), number of shoots/plant and leaves dry weight/plant (g).

Flowering characteristics: Flowering time (day) (time taking from planting to showing color of the first floret on spike), flower duration (days) (the number of days from flowering time to wilting of $75 \%$ florets of the total florets of inflorescence stalk), inflorescence stalk diameter $(\mathrm{cm})$, and inflorescence stalk dry weight $(\mathrm{g})$.

Root characteristics: Volume of roots $\left(\mathrm{cm}^{3}\right)$ and root dry weight ( $\mathrm{g}$ ).

Chemical analysis of leaves: Chlorophyll $a$ and $b$ content $(\mathrm{mg} / 100 \mathrm{~g}$ fresh weight) was determined according to Moran (1982), carotenoids (mg /100 g fresh weight according to Wellburn (1994), and total carbohydrate content (\%) according to Dubios et al. (1956).

Postharvest characteristics: At harvest, flower stalks grown from plants with different treatments with approximately $50 \%$ open florets were chosen for determination of postharvest characteristics. The stalks were re- cut to the length of $50 \mathrm{~cm}$ and the lower leaves of each stalk were removed from the stem prior to placing them in bottles with $500 \mathrm{ml}$ distilled water at 24 hours fluorescent light (about
500 lux), temperature of $23 \pm 2{ }^{\circ} \mathrm{C}$ and at $65-70 \%$ relative humidity.

Vase life (longevity): It was determined as day's number from beginning of holding flowers in distilled water $(\mathrm{pH}=6.79)$ till wilting of $75 \%$ florets of the total florets number of inflorescence stalk.

Final water uptake (g): It was calculated at the end of the experiment as

Water uptake $(\mathrm{g})=$ The amount of vase solution at the beginning of the experiment - the amount of the vase solution remaining at the end of the experiment. Loss of flower fresh weight percentage (LFFW): Change percentage in fresh weight of cut inflorescence stalk after 5 days beginning of holding flowers in distilled water. It was determined as the flowing

$$
\frac{\text { Initial fresh weight }- \text { Final fresh weight }}{\text { Initial fresh weight }}
$$

Floret opening percentage: It was calculated as a percentage of opened florets from the total florets number of inflorescence stalk at the end of longevity.

$$
=\frac{\text { Number of opened florets }}{\text { Nnumber of total florets }} \times 100
$$

\subsection{Experimental layout and statistical analysis}

The experiment layout was designed to provide complete randomized block design in factorial experiment, which contained three replicates, each replicate contained eight treatments. Four pots were used as an experimental unit for each treatment in each replicate. The means of the individual factors and their interactions were compared by L.S.D test at 5\% level of probability according to Snedecor and Cochran (1989). 


\section{RESULTS}

\subsection{Vegetative growth parameters:}

The analysis of variance showed that, the Fvalue of the different concentrations of diphenylamine was significant for all recorded vegetative data in the two experimental seasons. While, it was not significant for the application methods and the interaction between the concentrations and application methods of diphenylamine for all recorded vegetative data in the both seasons except the F-value of application methods for plant height which was significant in the two seasons.

\subsubsection{Plant height (cm)}

Data represented in Table (2) revealed that, during the two experimental seasons, the addition of diphenylamine at either 50 or $100 \mathrm{ppm}$ gave significant increases in plant height compared with the other treatments. On the other hand, using the highest concentration $(200 \mathrm{ppm})$ led to a significant decrease in plant height compared with the control treatment. The tallest plants $(61.61$ and $62.71 \mathrm{~cm}$ in the two seasons, respectively) were found by using
100 ppm. Besides, the foliar application of diphenylamine outperformed significantly compared to the soil application of it during the two seasons $(59.83$ and $59.66 \mathrm{~cm})$.

\subsubsection{Leaves number per plant}

Generally, using diphenylamine at any level significantly increased the number of leaves per plant, comparing with control treatment. The highest number of leaves per plant was obtained after using it at $200 \mathrm{ppm}$ comparing with the other treatments (167.11 and 212.78 leaf/plant) in the first and second season, respectively (Table 2).

\subsubsection{Leaf area per plant $(\mathrm{cm} 2)$}

Data recorded in Table (2) showed that, all the used concentrations of diphenylamine significantly increased the leaf area per plant as compared to control treatment during the two seasons. Moreover, the data cleared that, the maximum expansion of aster leaves (1496.03 and $1484.13 \mathrm{~cm}^{2}$ ) in the first and second season, respectively. was obtained from adding diphenylamine at $100 \mathrm{ppm}$.

Table 2. Means of plant height (cm), number of leaves/plant and leaf area/plant $\left(\mathrm{cm}^{2}\right)$ of $S$. novi-belgii L. cv white casablanca as influenced by different concentrations, application method of diphenylamine and their combinations during the two seasons of 2018 and 2019.

\begin{tabular}{|c|c|c|c|c|c|c|}
\hline \multicolumn{7}{|c|}{ Plant height $(\mathrm{cm})$} \\
\hline \multirow{3}{*}{$\begin{array}{c}\text { Diphenylamine } \\
\text { concentrations }(\mathrm{A}) \\
(\mathrm{ppm})\end{array}$} & \multicolumn{2}{|c|}{2018} & \multirow{3}{*}{ Mean (A) } & \multicolumn{2}{|c|}{2019} & \multirow{3}{*}{ Mean $(\mathrm{A})$} \\
\hline & \multicolumn{2}{|c|}{ Application methods (B) } & & \multicolumn{2}{|c|}{ Application methods (B) } & \\
\hline & Soil drench & Foliar spray & & Soil drench & Foliar spray & \\
\hline 0 & 52.19 & 59.28 & 55.74 & 54.56 & 58.01 & 56.28 \\
\hline 50 & 57.94 & 64.11 & 61.03 & 57.93 & 63.58 & 60.76 \\
\hline 100 & 59.33 & 63.89 & 61.61 & 60.44 & 64.97 & 62.71 \\
\hline 200 & 48.89 & 52.06 & 50.47 & 49.90 & 52.08 & 50.99 \\
\hline Mean (B) & 54.59 & 59.83 & & 55.71 & 59.66 & \\
\hline L.S.D. at 0.05 & $A=3.67$ & $\mathrm{~B}=5.20$ & $\mathrm{AxB}=\mathrm{N} . \mathrm{S}$ & $\mathrm{A}=2.72$ & $\mathrm{~B}=3.85$ & $\mathrm{AxB}=\mathrm{N} . \mathrm{S}$ \\
\hline \multicolumn{7}{|c|}{ Number of leaves/plant } \\
\hline 0 & 81.64 & 81.14 & 81.39 & 82.67 & 100.44 & 91.56 \\
\hline 50 & 121.94 & 116.00 & 119.97 & 167.78 & 120.00 & 143.89 \\
\hline 100 & 118.67 & 172.78 & 145.72 & 172.56 & 158.56 & 165.56 \\
\hline 200 & 150.56 & 183.67 & 167.11 & 194.89 & 230.67 & 212.78 \\
\hline Mean (B) & 118.20 & 138.40 & & 154.47 & 152.42 & \\
\hline L.S.D. at 0.05 & $\mathrm{~A}=37.85$ & $\mathrm{~B}=\mathrm{N} . \mathrm{S}$ & $\mathrm{AXB}=\mathrm{N} . \mathrm{S}$ & $\mathrm{A}=47.29$ & $\mathrm{~B}=\mathrm{N} . \mathrm{S}$ & $\mathrm{AXB}=\mathrm{N} . \mathrm{S}$ \\
\hline \multicolumn{7}{|c|}{ Leaf area/plant $\left(\mathrm{cm}^{2}\right)$} \\
\hline 0 & 629.35 & 667.02 & 648.19 & 614.98 & 699.68 & 657.33 \\
\hline 50 & 975.25 & 1152.84 & 1064.04 & 1242.02 & 1140.97 & 1191.49 \\
\hline 100 & 1465.90 & 1526.15 & 1496.03 & 1466.77 & 1501.49 & 1484.13 \\
\hline 200 & 1307.87 & 1301.47 & 1304.67 & 1398.95 & 1399.75 & 1399.35 \\
\hline Mean (B) & 1094.59 & 1161.87 & & 1180.68 & 1185.47 & \\
\hline L.S.D. at 0.05 & $\mathrm{~A}=182.55$ & $\mathrm{~B}=\mathrm{N} . \mathrm{S}$ & $\mathrm{AXB}=\mathrm{N} \cdot \mathrm{S}$ & $A=246.51$ & $B=N . S$ & $\mathrm{AXB}=\mathrm{N} . \mathrm{S}$ \\
\hline
\end{tabular}

L.S.D. at $0.05=$ least significant different at 0.05 probability. $\quad \mathrm{N} . \mathrm{S}=$ not significant. 


\subsubsection{Number of shoots/plant}

Data of two seasons in Table (3) cleared that the addition of any level of diphenylamine caused significant increase in the number of shoots/plant compared to control treatment. Furthermore, data showed that the highest values of number of shoots/plant was recorded by using the treatment of diphenylamine at $100 \mathrm{ppm}(19.25$ and 22.11 shoots/plant in the first and second season, respectively).

\subsubsection{Leaves dry weight (g)}

Table (3) showed that the addition of diphenylamine at 50,100 or $200 \mathrm{ppm}$ led to a significant increase in leaves dry weight compared to control treatment during the two seasons. Also, application of diphenylamine at $100 \mathrm{ppm}$ produced the highest increment of leaves dry weight which was 20.13 and $22.20 \mathrm{~g}$ in the first and second season respectively.

Table 3. Means of number of shoots/plant and leaves dry weight/plant (g) of S. novi-belgii $\mathbf{L}$. cv white casablanca as influenced by different concentrations, application method of diphenylamine and their combinations during the two seasons of 2018 and 2019.

\begin{tabular}{|c|c|c|c|c|c|c|}
\hline \multicolumn{7}{|c|}{ Number of shoots/plant } \\
\hline \multirow{3}{*}{$\begin{array}{c}\text { Diphenylamine } \\
\text { concentrations(A) } \\
(\mathrm{ppm})\end{array}$} & \multicolumn{2}{|c|}{2018} & \multirow{3}{*}{ Mean (A) } & \multicolumn{2}{|c|}{2019} & \multirow{3}{*}{ Mean (A) } \\
\hline & \multicolumn{2}{|c|}{ Application methods (B) } & & \multicolumn{2}{|c|}{ Application methods (B) } & \\
\hline & Soil drench & Foliar spray & & Soil drench & Foliar spray & \\
\hline 0 & 8.75 & 10.44 & 9.60 & 10.78 & 12.92 & 11.85 \\
\hline 50 & 16.33 & 13.00 & 14.67 & 16.75 & 17.39 & 17.07 \\
\hline 100 & 16.56 & 21.94 & 19.25 & 19.67 & 24.56 & 22.11 \\
\hline 200 & 14.28 & 18.61 & 16.44 & 19.00 & 21.50 & 20.25 \\
\hline Mean (B) & 13.98 & 16.00 & & 16.55 & 19.09 & \\
\hline L.S.D. at 0.05 & $A=3.59$ & $\mathrm{~B}=\mathrm{N} . \mathrm{S}$ & $\mathrm{AxB}=\mathrm{N} . \mathrm{S}$ & $\mathrm{A}=4.79$ & $\mathrm{~B}=\mathrm{N} . \mathrm{S}$ & $\mathrm{AxB}=\mathrm{N} . \mathrm{S}$ \\
\hline \multicolumn{7}{|c|}{ leaves dry weight/plant $(\mathrm{g})$} \\
\hline 0 & 7.96 & 11.01 & 9.48 & 9.46 & 10.78 & 10.12 \\
\hline 50 & 18.20 & 19.88 & 19.04 & 14.33 & 19.73 & 17.03 \\
\hline 100 & 18.57 & 21.69 & 20.13 & 19.07 & 25.33 & 22.20 \\
\hline 200 & 19.81 & 19.14 & 19.47 & 17.90 & 17.93 & 17.91 \\
\hline Mean (B) & 16.13 & 17.93 & & 15.19 & 18.44 & \\
\hline L.S.D. at 0.05 & $\mathrm{~A}=3.52$ & $\mathrm{~B}=\mathrm{N} . \mathrm{S}$ & $\mathrm{AXB}=\mathrm{N} . \mathrm{S}$ & $A=4.13$ & $\mathrm{~B}=\mathrm{N} . \mathrm{S}$ & $\mathrm{AXB}=\mathrm{N} . \mathrm{S}$ \\
\hline
\end{tabular}

L.S.D. at $0.05=$ least significant different at 0.05 probability.

\subsection{Flowering Characteristics:}

The analysis of variance cleared that, the Fvalue of the different concentrations of diphenylamine was significant for all recorded flowering characteristics in the two experimental seasons. While, it was not significant for the application methods and the interaction between the concentrations and application methods of diphenylamine during the two seasons except the $\mathrm{F}$ value of the application methods for the inflorescence stalk dry weight parameter which was significant in the two seasons.

\subsubsection{Flowering Time (days)}

The reported data in Table (4) indicated that, using any level of the diphenylamine led to a significant reduction in the number of days needed for flowering, compared with the control treatment. Furthermore, the application of diphenylamine at $200 \mathrm{ppm}$ gave the minimum time needed for flowering of aster (282.83 and 286.67 days in the first and second seasons, respectively) compared with other treatments in the two seasons, but it has the same level of significant of using $50 \mathrm{ppm}$.

\subsubsection{Flowering duration (days)}

Data of means of flowering duration of the two experimental seasons indicated that, the application of diphenylamine at 50 or $100 \mathrm{ppm}$ led to a significant increase (at the same level of significant) as compared to the control treatment. On the other hand, using $200 \mathrm{ppm}$ did not cause any significant increase in the flowering duration compared with the control treatment (Table 4). Furthermore, the addition of diphenylamine at 50 ppm gave the longest flowering duration on the plant which led to increase the flowering duration with 13.86 and 17.92 days over the control treatment in the first and second season respectively.

\subsubsection{Inflorescence stalk diameter (cm)}

Data in Table (4) showed that the inflorescence stalk diameter of aster plant 
significantly increased by applying diphenylamine only at 50 or $100 \mathrm{ppm}$ as comparing with the control treatment. The maximum diameter was obtained from the addition $100 \mathrm{ppm}(0.58$ and $0.63 \mathrm{~cm})$ in the first and second season respectively.

\subsubsection{Inflorescence stalk dry weight (g)}

Table (4) cleared that either using 50 or 100 ppm of diphenylamine led to a significant increase in dry weight of stalk compared to the control treatment. The highest increase in dry weight was obtained after using $100 \mathrm{ppm}$ (24.77 and $30.79 \mathrm{~g}$ ). Also, foliar spray of diphenylamine led to a significant increase in inflorescence stalk dry weight compared with the soil drench of it (16.83 and 20.90 g) in the first and second seasons respectively.

Table 4. Means of flowering time (days), flower duration (days), inflorescence stalk diameter (cm) and inflorescence stalk dry weight (g) of $S$. novi-belgii $\mathrm{L}$. $\mathrm{cv}$ white casablanca as influenced by different concentrations, application method of diphenylamine and their combination during the two seasons of 2018 and 2019.

\begin{tabular}{|c|c|c|c|c|c|c|}
\hline \multicolumn{7}{|c|}{ Flowering time (days) } \\
\hline \multirow{3}{*}{$\begin{array}{c}\text { Diphenylamine } \\
\text { concentrations(A) } \\
(\mathrm{ppm})\end{array}$} & \multicolumn{2}{|c|}{2018} & \multirow{3}{*}{ Mean (A) } & \multicolumn{2}{|c|}{2019} & \multirow{3}{*}{ Mean (A) } \\
\hline & \multicolumn{2}{|c|}{ Application methods (B) } & & \multicolumn{2}{|c|}{ Application methods (B) } & \\
\hline & Soil drench & Foliar spray & & Soil drench & Foliar spray & \\
\hline 0 & 332.67 & 302.90 & 331.47 & 330.50 & 300.17 & 332.29 \\
\hline 50 & 289.27 & 330.27 & 292.14 & 283.83 & 334.08 & 287.11 \\
\hline 100 & 305.67 & 295.00 & 303.38 & 303.53 & 290.38 & 304.26 \\
\hline 200 & 284.00 & 301.08 & 282.83 & 282.00 & 305.00 & 286.67 \\
\hline Mean (B) & 281.67 & 302.01 & & 291.34 & 305.97 & \\
\hline L.S.D. at 0.05 & $A=10.25$ & $B=N . S$ & $\mathrm{AxB}=\mathrm{N} . \mathrm{S}$ & $\mathrm{A}=18.93$ & $\mathrm{~B}=\mathrm{N} \cdot \mathrm{S}$ & $\mathrm{AxB}=\mathrm{N} . \mathrm{S}$ \\
\hline \multicolumn{7}{|c|}{ Flower duration (days) } \\
\hline 0 & 19.68 & 19.35 & 19.51 & 19.17 & 16.78 & 17.97 \\
\hline 50 & 31.85 & 34.90 & 33.37 & 34.61 & 37.17 & 35.89 \\
\hline 100 & 31.03 & 31.33 & 31.18 & 31.78 & 35.17 & 33.47 \\
\hline 200 & 22.66 & 20.58 & 21.62 & 23.67 & 19.00 & 21.33 \\
\hline Mean (B) & 26.30 & 26.54 & & 27.31 & 27.03 & \\
\hline L.S.D. at 0.05 & $A=3.68$ & $\mathrm{~B}=\mathrm{N} . \mathrm{S}$ & $\mathrm{AXB}=\mathrm{N} . \mathrm{S}$ & $A=4.78$ & $\mathrm{~B}=\mathrm{N} . \mathrm{S}$ & $\mathrm{AXB}=\mathrm{N} \cdot \mathrm{S}$ \\
\hline \multicolumn{7}{|c|}{ Inflorescence stalk diameter $(\mathrm{cm})$} \\
\hline 0 & 0.46 & 0.48 & 0.47 & 0.47 & 0.49 & 0.48 \\
\hline 50 & 0.54 & 0.52 & 0.54 & 0.58 & 0.58 & 0.58 \\
\hline 100 & 0.60 & 0.56 & 0.58 & 0.65 & 0.61 & 0.63 \\
\hline 200 & 0.52 & 0.45 & 0.49 & 0.47 & 0.46 & 0.47 \\
\hline Mean (B) & 0.53 & 0.50 & & 0.54 & 0.54 & \\
\hline L.S.D. at 0.05 & $A=0.06$ & $\mathrm{~B}=\mathrm{N} . \mathrm{S}$ & $\mathrm{AXB}=\mathrm{N} . \mathrm{S}$ & $\mathrm{A}=0.04$ & $\mathrm{~B}=\mathrm{N} . \mathrm{S}$ & $\mathrm{AXB}=\mathrm{N} \cdot \mathrm{S}$ \\
\hline \multicolumn{7}{|c|}{ Inflorescence stalk dry weight $(\mathrm{g})$} \\
\hline 0 & 9.38 & 9.81 & 9.59 & 11.02 & 10.97 & 10.99 \\
\hline 50 & 14.97 & 16.78 & 15.87 & 21.95 & 25.44 & 23.70 \\
\hline 100 & 21.32 & 28.22 & 24.77 & 27.87 & 33.72 & 30.79 \\
\hline 200 & 12.19 & 12.53 & 12.36 & 12.62 & 13.47 & 13.04 \\
\hline Mean (B) & 14.47 & 16.83 & & 18.36 & 20.90 & \\
\hline L.S.D. at 0.05 & $A=2.78$ & $B=1.97$ & $\mathrm{AXB}=\mathrm{N} . \mathrm{S}$ & $\mathrm{A}=2.39$ & $B=1.69$ & $\mathrm{AXB}=\mathrm{N} . \mathrm{S}$ \\
\hline
\end{tabular}

L.S.D. at $0.05=$ least significant different at 0.05 probability. $\quad$ N.S $=$ not significant.

\subsection{Root characteristics:}

The analysis of variance showed that, the Fvalue of the different concentrations of diphenylamine was significant for all recorded data in the two experimental seasons. While, it was not significant for the application methods and the interaction between the concentrations and application methods of diphenylamine for all recorded data in both seasons.

\subsubsection{Root volume $\left(\mathrm{cm}^{3}\right)$}

Data in Table (5) showed that application of diphenylamine with any of the tested concentrations gave a significant increase in root volume compared with the control treatment. However, the greatest volume of root was obtained by using $100 \mathrm{ppm}$ of diphenylamine $\left(89.17\right.$ and $\left.101.39 \mathrm{~cm}^{3}\right)$ in the first and second season respectively. 


\subsubsection{Root dry weight (g)}

Data in Table (5) cleared that all concentrations of diphenylamine gave a significant increase in root dry weight as compared with the control treatment. Moreover, the greatest dry weight of root was obtained by using $100 \mathrm{ppm}$ of diphenylamine (20.80 and $22.20 \mathrm{~g}$ ) in the first and second season respectively.

Table 5. Means of root volume $\left(\mathrm{cm}^{3}\right)$ and root dry weight $(\mathrm{g})$ of $S$. novi-belgii $\mathrm{L}$. cv white casablanca as influenced by different concentrations, application method of diphenylamine and their combinations during the two seasons of 2018 and 2019.

\begin{tabular}{|c|c|c|c|c|c|c|}
\hline \multicolumn{7}{|c|}{ Root volume $\left(\mathrm{cm}^{3}\right)$} \\
\hline \multirow{3}{*}{$\begin{array}{l}\text { Diphenylamine } \\
\text { concentrations(A) } \\
\text { (ppm) }\end{array}$} & \multicolumn{2}{|c|}{2018} & \multirow{3}{*}{ Mean (A) } & \multicolumn{2}{|c|}{2019} & \multirow{3}{*}{ Mean (A) } \\
\hline & \multicolumn{2}{|c|}{ Application methods (B) } & & \multicolumn{2}{|c|}{ Application methods (B) } & \\
\hline & Soil drench & Foliar spray & & Soil drench & Foliar spray & \\
\hline 0 & 27.50 & 33.33 & 30.42 & 33.33 & 35.83 & 34.58 \\
\hline 50 & 75.00 & 74.44 & 74.72 & 71.11 & 75.83 & 73.47 \\
\hline 100 & 85.00 & 93.33 & 89.17 & 90.56 & 112.22 & 101.39 \\
\hline 200 & 83.33 & 90.56 & 86.94 & 87.22 & 88.33 & 87.78 \\
\hline Mean (B) & 67.71 & 72.92 & & 70.56 & 78.06 & \\
\hline L.S.D. at 0.05 & $\mathrm{~A}=13.93$ & $B=N . S$ & $\mathrm{AxB}=\mathrm{N} . \mathrm{S}$ & $\mathrm{A}=10.76$ & $\mathrm{~B}=\mathrm{N} . \mathrm{S}$ & $\mathrm{AxB}=\mathrm{N} . \mathrm{S}$ \\
\hline \multicolumn{7}{|c|}{ Root dry weight $(\mathrm{g})$} \\
\hline 0 & 7.68 & 9.70 & 8.69 & 9.46 & 10.78 & 10.12 \\
\hline 50 & 17.11 & 16.72 & 16.91 & 14.33 & 19.73 & 17.03 \\
\hline 100 & 20.28 & 21.33 & 20.80 & 19.07 & 25.33 & 22.20 \\
\hline 200 & 17.08 & 19.27 & 18.17 & 17.90 & 17.93 & 17.91 \\
\hline Mean (B) & 15.53 & 16.75 & & 15.19 & 18.44 & \\
\hline L.S.D. at 0.05 & $\mathrm{~A}=3.27$ & $B=N . S$ & $\mathrm{AXB}=\mathrm{N} . \mathrm{S}$ & $\mathrm{A}=4.13$ & $B=N . S$ & $\mathrm{AXB}=\mathrm{N} \cdot \mathrm{S}$ \\
\hline
\end{tabular}

L.S.D. at $0.05=$ least significant different at 0.05 probability.

\subsection{Postharvest characteristics:}

The analysis of variance showed that, only the F-value of the concentrations of diphenylamine was significant for all recorded data in the two experimental seasons.

\subsubsection{Vase life (days)}

Data recorded in Table (6) indicated that, using 50 or $100 \mathrm{ppm}$ of diphenylamine increased the vase life of cut flower with the same level of significant in both seasons as compared to the control treatment. On the other hand, using $200 \mathrm{ppm}$ of it caused a significant decrease in the vase life as compared to control, which gave 7.33 and 7.67 day in first and second season. However, the longest significant vase life was obtained after using diphenylamine at 100 ppm which was 11.50 and 12.67 day in the two seasons respectively (21.05 and $35.80 \%$ more than the control in the two seasons, respectively).

\subsubsection{Final water uptake (g)}

As general, the final water uptake of cut flower was increased by application of diphenylamine. The highest significant increase in final water uptake was occurred by using of 100 ppm which was 218.40 and $226.20 \mathrm{~g}$ during the first and second seasons respectively (37.82 and $34.10 \%$ more than the control in the two seasons respectively) (Table 6).

\subsubsection{Loss of flower fresh weight percentage (LFFW) (\%)}

Data recorded in Table (6) cleared that, only using 50 or $100 \mathrm{ppm}$ of diphenylamine decreased the LFFW significantly as compared to control treatment with the same level of significant in both seasons. However, the lowest LFFW was obtained after application diphenylamine by $100 \mathrm{ppm}$ which was 15.79 and $12.44 \%$ in the first and second seasons respectively (51.25 and 59.39\% less than the control in the two seasons, respectively).

\subsubsection{Floret opening percentage (\%)}

Table (6) show that, there was a significant increase in floret opening percentage after application of diphenylamine by 50 or $100 \mathrm{ppm}$ comparing with the control treatment with the same level of significant in both seasons. Results cleared that the highest floret opening percentage was obtained after using DPA by $100 \mathrm{ppm}$, which was 91.63 and $89.66 \%$ in the first and second seasons respectively ( 18.73 and $19.11 \%$ less than the control in the two seasons, respectively). 
Table 6. Means of Vase life (days), Final water uptake (g) and Loss of flower fresh weight percentage LFFW (\%) and Floret opening (\%) of $S$. novi-belgii $\mathrm{L}$. cv white casablanca as influenced by different concentrations, application method of diphenylamine and their combinations during the two seasons of 2018 and 2019.

\begin{tabular}{|c|c|c|c|c|c|c|}
\hline \multicolumn{7}{|c|}{ Vase life (days) } \\
\hline \multirow{3}{*}{$\begin{array}{c}\text { Diphenylamine } \\
\text { concentrations(A) } \\
(\mathrm{ppm})\end{array}$} & \multicolumn{2}{|c|}{2018} & \multirow{3}{*}{ Mean $(A)$} & \multicolumn{2}{|c|}{2019} & \multirow{3}{*}{ Mean (A) } \\
\hline & \multicolumn{2}{|c|}{ Application methods (B) } & & \multicolumn{2}{|c|}{ Application methods (B) } & \\
\hline & Soil drench & Foliar spray & & Soil drench & Foliar spray & \\
\hline 0 & 9.67 & 9.33 & 9.50 & 9.33 & 9.33 & 9.33 \\
\hline 50 & 11.00 & 11.67 & 11.33 & 11.33 & 12.00 & 11.67 \\
\hline 100 & 11.33 & 11.67 & 11.50 & 12.67 & 12.67 & 12.67 \\
\hline 200 & 7.00 & 7.67 & 7.33 & 6.67 & 8.67 & 7.67 \\
\hline Mean (B) & 9.75 & 10.08 & & 10.00 & 10.67 & \\
\hline L.S.D. at 0.05 & $\mathrm{~A}=1.45$ & $B=N \cdot S$ & $\mathrm{AxB}=\mathrm{N} . \mathrm{S}$ & $\mathrm{A}=1.85$ & $B=N \cdot S$ & $\mathrm{AxB}=\mathrm{N} \cdot \mathrm{S}$ \\
\hline \multicolumn{7}{|c|}{ Final water uptake $(\mathrm{g})$} \\
\hline 0 & 156.05 & 160.89 & 158.47 & 159.63 & 177.72 & 168.68 \\
\hline 50 & 194.98 & 204.06 & 199.52 & 183.00 & 229.82 & 206.41 \\
\hline 100 & 193.40 & 243.40 & 218.40 & 214.49 & 237.92 & 226.20 \\
\hline 200 & 130.00 & 120.79 & 125.40 & 119.60 & 121.33 & 120.47 \\
\hline Mean (B) & 168.61 & 182.28 & & 169.18 & 191.70 & \\
\hline L.S.D. at 0.05 & $A=50.26$ & $B=N . S$ & $\mathrm{AXB}=\mathrm{N} . \mathrm{S}$ & $\mathrm{A}=52.95$ & $B=N \cdot S$ & $\mathrm{AXB}=\mathrm{N} \cdot \mathrm{S}$ \\
\hline \multicolumn{7}{|c|}{ Loss of flower fresh weight percentage LFFW (\%) } \\
\hline 0 & 31.50 & 33.28 & 32.39 & 31.60 & 29.66 & 30.63 \\
\hline 50 & 20.12 & 18.45 & 19.28 & 18.69 & 15.28 & 16.99 \\
\hline 100 & 15.53 & 16.06 & 15.79 & 13.35 & 11.54 & 12.44 \\
\hline 200 & 32.53 & 32.47 & 32.50 & 28.34 & 30.28 & 29.31 \\
\hline Mean (B) & 24.92 & 25.06 & & 22.99 & 21.69 & \\
\hline L.S.D. at 0.05 & $\mathrm{~A}=8.88$ & $B=N . S$ & $\mathrm{AXB}=\mathrm{N} . \mathrm{S}$ & $A=6.16$ & $B=N \cdot S$ & $\mathrm{AXB}=\mathrm{N} \cdot \mathrm{S}$ \\
\hline \multicolumn{7}{|c|}{ Floret opening (\%) } \\
\hline 0 & 76.67 & 77.68 & 77.17 & 73.89 & 76.67 & 75.28 \\
\hline 50 & 87.00 & 85.74 & 86.37 & 86.00 & 88.93 & 87.47 \\
\hline 100 & 90.44 & 92.82 & 91.63 & 88.99 & 90.33 & 89.66 \\
\hline 200 & 77.59 & 66.33 & 71.96 & 77.93 & 64.67 & 71.30 \\
\hline Mean (B) & 82.92 & 80.64 & & 81.70 & 80.15 & \\
\hline L.S.D. at 0.05 & $A=7.94$ & $B=1.97$ & $\mathrm{AXB}=\mathrm{N} . \mathrm{S}$ & $\mathrm{A}=2.39$ & $B=6.45$ & $\mathrm{AXB}=\mathrm{N} . \mathrm{S}$ \\
\hline
\end{tabular}

L.S.D. at $0.05=$ least significant different at 0.05 probability.

\subsection{Chemical characteristics:}

The analysis of variance showed that, only the F-value of the different concentrations of diphenylamine was significant for all recorded data in the two experimental seasons with one exception of the $\mathrm{F}$ value of the interaction between the concentrations and application methods of diphenylamine in chlorophyll $b$ which was significant in the second season.

\subsubsection{Chlorophyll a and b content $(\mathrm{mg} / 100 \mathrm{~g}$ fresh weight)}

Data in Table (7) show that, using of diphenylamine by any level caused significant increase in chlorophyll $\mathrm{a}$ and $\mathrm{b}$ as compared to control treatment during the two seasons. However, the highest increase in chlorophyll a and $b$ in both seasons was obtained by applying diphenylamine at $100 \mathrm{ppm}$, which was 151.60 and $157.85 \mathrm{mg} / 100 \mathrm{~g}$ fresh weight for chlorophyll and 44.71 and 49.09 $\mathrm{mg} / 100 \mathrm{~g}$ fresh weight for chlorophyll $\mathrm{b}$ in the first and second seasons, respectively.

\subsubsection{Total carotenoids content $(\mathrm{mg} / 100 \mathrm{~g}$ fresh weight)}

Data in Table (7) cleared that, using of diphenylamine by 50 or $100 \mathrm{ppm}$ caused significant increase in leaves content of carotenoids as compared to the control treatment during the two seasons. However, application of $100 \mathrm{ppm}$ gave the highest increase in carotenoids comparing with the other treatments which was 396.76 and 425.94 $\mathrm{mg} / 100 \mathrm{~g}$ fresh weight in the first and second seasons, respectively.

\subsubsection{Total carbohydrates content (\%)}

Data reported in Table (7) explain that, there was a significant difference after applying different concentration of diphenylamine on carbohydrates content as compared to the control treatment and the highest carbohydrates content (12.36 and $12.91 \%$ in 
Table 7. Means of chlorophyll a, $b(\mathrm{mg} / 100 \mathrm{~g}$ fresh weight), total carotenoids (mg/100g fresh weight) and total carbohydrates contents $(\%)$ of $S$. novi-belgii $\mathrm{L}$. $\mathrm{cv}$ white casablanca as influenced by different concentrations, application method of diphenylamine and their combinations during the two seasons of 2018 and 2019.

\begin{tabular}{|c|c|c|c|c|c|c|}
\hline \multicolumn{7}{|c|}{ Chlorophyll a (mg/100g fresh weight) } \\
\hline \multirow{3}{*}{$\begin{array}{c}\text { Diphenylamine } \\
\text { concentrations(A) } \\
(\mathrm{ppm})\end{array}$} & \multirow{2}{*}{\multicolumn{2}{|c|}{$\begin{array}{c}2018 \\
\text { Application methods (B) }\end{array}$}} & \multirow{3}{*}{ Mean (A) } & \multicolumn{2}{|c|}{2019} & \multirow{3}{*}{ Mean (A) } \\
\hline & & & & \multicolumn{2}{|c|}{ Application methods (B) } & \\
\hline & Soil drench & Foliar spray & & Soil drench & Foliar spray & \\
\hline 0 & 73.02 & 117.81 & 95.42 & 90.02 & 78.67 & 84.35 \\
\hline 50 & 152.36 & 134.63 & 143.50 & 152.14 & 156.66 & 154.40 \\
\hline 100 & 156.56 & 146.64 & 151.60 & 154.93 & 160.76 & 157.85 \\
\hline 200 & 118.82 & 107.70 & 113.26 & 134.26 & 124.43 & 129.34 \\
\hline Mean (B) & 125.19 & 126.70 & & 132.84 & 130.13 & \\
\hline L.S.D. at 0.05 & $\mathrm{~A}=23.87$ & $\mathrm{~B}=\mathrm{N} \cdot \mathrm{S}$ & $\mathrm{AxB}=\mathrm{N} . \mathrm{S}$ & $\mathrm{A}=25.03$ & $B=N . S$ & $\mathrm{AxB}=\mathrm{N} . \mathrm{S}$ \\
\hline \multicolumn{7}{|c|}{ Chlorophyll b (mg/100g fresh weight) } \\
\hline 0 & 25.41 & 35.55 & 30.48 & 29.61 & 29.67 & 29.64 \\
\hline 50 & 48.02 & 37.60 & 42.81 & 50.22 & 39.49 & 44.86 \\
\hline 100 & 43.24 & 46.17 & 44.71 & 32.38 & 65.80 & 49.09 \\
\hline 200 & 43.14 & 40.03 & 41.58 & 29.79 & 32.76 & 31.27 \\
\hline Mean (B) & 39.95 & 39.84 & & 35.50 & 41.93 & \\
\hline L.S.D. at 0.05 & $\mathrm{~A}=7.00$ & $\mathrm{~B}=\mathrm{N} . \mathrm{S}$ & $\mathrm{AXB}=\mathrm{N} . \mathrm{S}$ & $\mathrm{A}=10.73$ & $\mathrm{~B}=\mathrm{N} . \mathrm{S}$ & $\mathrm{AXB}=15.17$ \\
\hline \multicolumn{7}{|c|}{ Total Carotenoids (mg/100g fresh weight) } \\
\hline 0 & 231.07 & 334.88 & 282.98 & 304.95 & 211.10 & 258.03 \\
\hline 50 & 408.91 & 373.78 & 391.35 & 406.47 & 416.90 & 411.68 \\
\hline 100 & 412.02 & 381.50 & 396.76 & 411.46 & 440.43 & 425.94 \\
\hline 200 & 296.53 & 287.71 & 292.12 & 346.93 & 322.70 & 334.82 \\
\hline Mean (B) & 337.13 & 344.47 & & 367.45 & 347.78 & \\
\hline L.S.D. at 0.05 & $A=69.56$ & $\mathrm{~B}=\mathrm{N} . \mathrm{S}$ & $\mathrm{AXB}=\mathrm{N} . \mathrm{S}$ & $\mathrm{A}=65.59$ & $\mathrm{~B}=\mathrm{N} . \mathrm{S}$ & $\mathrm{AXB}=\mathrm{N} . \mathrm{S}$ \\
\hline \multicolumn{7}{|c|}{ Total Carbohydrates contents $(\%)$} \\
\hline 0 & 9.86 & 9.90 & 9.88 & 9.45 & 10.53 & 9.99 \\
\hline 50 & 10.90 & 10.93 & 10.92 & 11.24 & 11.53 & 11.38 \\
\hline 100 & 12.00 & 12.71 & 12.36 & 12.67 & 13.15 & 12.91 \\
\hline 200 & 11.41 & 11.60 & 11.50 & 11.88 & 11.86 & 11.87 \\
\hline Mean (B) & 11.04 & 11.29 & & 11.31 & 11.77 & \\
\hline L.S.D. at 0.05 & $\mathrm{~A}=1.08$ & $\mathrm{~B}=\mathrm{N} . \mathrm{S}$ & $\mathrm{AXB}=\mathrm{N} . \mathrm{S}$ & $\mathrm{A}=1.30$ & $\mathrm{~B}=\mathrm{N} . \mathrm{S}$ & $\mathrm{AXB}=\mathrm{N} . \mathrm{S}$ \\
\hline
\end{tabular}

L.S.D. at $0.05=$ least significant different at 0.05 probability. $\quad$ N.S $=$ not significant.

the first and second seasons, respectively) was obtained from using $100 \mathrm{ppm}$.

\section{DISCUSSION}

The results cleared that all studied vegetative and root growth parameters significantly increased after application of DPA at any of the tested concentration levels as compared to control. Furthermore, using DPA at $100 \mathrm{ppm}$ resulted in the highest increase in plant height, leaves area, number of shoots per plant and leaves dry weight, while, the highest number of leaves was obtained after using DPA at $200 \mathrm{ppm}$. These results may be due to using DPA that resulted in activation the biosynthesizes processes inside the plant which led to increase of cell division and/or enlargement or both which improve, consequently the vegetative growth parameters .Moreover, DPA may exhilarate growth by rising accumulations of the dry matter especially carbohydrates and protein (Karagianniset al., 2018).These results are in agreement with those obtained by Abou Dahab and Abdel-Aziz, (2006) on Philodendron erubescensand Naglaa et al., (2011)on tuberose

Generally, results of the two seasons indicated that using DPA at 50 or $100 \mathrm{ppm}$ caused a significant increase in flower duration, inflorescence stalk diameter and dry weight compared with control treatment. Also, using any level of the diphenylamine led to a significant reduction in the number of days needed for flowering, compared with the control treatment. These results may be due to that presence of DPA can promote the composition of auxins, protein or enzymes (John et al., 1997 and Karagiannis et al., 2018), Moreover, this amendment in $\mathrm{f}$ lowering growth characteristics 
perhaps it is due to the remarkable improvement in the vegetative growth of the plant which in turn increased the flower characteristics.

These results agree with those obtained by Eman et al., (2012) on glandulous and Naglaa et al., (2011) on tuberose.

Also, the results showed that the values of chlorophyll a, chlorophyll $\mathrm{b}$ and total carotinoides content were increased significantly as result of using DPA at 50 or $100 \mathrm{ppm}$ during the two seasons. This increment may be due to the effect of DPA as an antioxidant on preservation the plant pigments from degradation and delaying its senescence consequentially the chlorophyll $\mathrm{a}$ and $\mathrm{b}$ in leaves could be increased. These results are in harmony with those obtained by Abou Dahab and AbdelAziz, (2006) on Philodendron erubescens and Eman and Amira, (2014) on Dendranthema grandiflorum. The increase in chlorophyll $\mathrm{a}$ and $\mathrm{b}$ leads to $\mathrm{a}$ consequent increase in total carbohydrates (Stinoet al.,2009). Similar findings were obtained by Naglaa et al., (2011) on tuberose.

The application of DPA at (50 and $100 \mathrm{ppm})$ led to significant improvement of cut flower quality. Using of DPA at $100 \mathrm{ppm}$ gave the longest vase life and the highest floret opening percentage which it could be attributed to the ability of DPA in inhibition Polyphenol oxidase (PPO) activity and its general effect as antioxidant (Lurie et al., 1989), where DPA acts as scavenger and prevent cells and tissues damage and delay the flowering senescence as mentioned by Naglaa et al., (2011). Also, DPA reduced respiration (Purvis and Gegogeine, 2003) and ethylene production by cells Du and Bramlage (1994). Furthermore, the results cleared that lowest LFFW and highest final water uptake was obtained after applying the same treatment which explain the highest vase life obtained after this treatment (Rida, 2019).

\section{CONCLUSION}

Based on the previous results, it could recommend using diphenylamine (DPA) at $100 \mathrm{ppm}$ as foliar spray treatment four times 30,60, 90 and 120 days after final transplanting. This treatment resulted in the highest values of plant height, leaf area, number of shoots/plant, leaves dry weight, diameter and dry weight of inflorescence stalk, root volume and dry weight and leaves chlorophyll, total carotenoids and total carbohydrate contents. Besides, this treatment caused the longest vase life, the highest final water uptake and floret opening percentage and the lowest loss of flower fresh weight percentage.

\section{REFERENCES}

Abou Dahab T, Abdel-Aziz N(2006). Physiological effect of diphenylamine and tryptophan on the growth and chemical constituents of Philodendron erubescens plants. World J. of Agri. Sci., 2 (1): 75 81.

Cindy D, Ana LA, Ângelo CS, Armando JD, Sílvia MR, Nélson I, Manuela P(2020). Strategies to Preserve Postharvest Quality of Horticultural Crops and Superficial Scald Control: From Diphenylamine Antioxidant Usage to More Recent Approaches. Antioxidants 9(4):356.

Du Z, Bramlage WJ(1994). Roles of ethylene in the development of superficial scald in 'Cortland' apples. J. Am. Soc. Hortic. Sci., 119: 516-523.

Dubios M, Gilles K, Hamlton J, Rebers P, Smith $\mathbf{F}(\mathbf{1 9 5 6})$. Colourimetric method for determination of sugars and related substances. Anal. Chem., 28(3): 350- 356.

Eman S, Amira O (2014). Influence of Diphenylamine and Ascorbic acid on the production of Dendranthema grandiflorum, Ram. Life Sci. J., 11(9) 846-852.

Eman S, El-Naggar HH, Amira O (2012). Effect of Nitrogen and Diphenylamine on Gladiolus hybridacv. Sancerre Production. J. Hort. Sci. \& Orna.. Plants, 4 (3): 267-274.

Huelin FE, Coggiola IM (1970). Superficial scald, a functional disorder of stored apples. V.- Oxidation of $\alpha$-farnesene and its inhibition by diphenylamine. J. Sci. Food Agric.,21, 44-48.

John A, Paul T, Siddique M (1997). Nutritional studies in gladiolus 1: Growth and floral characters Advanced in plant Sci., 10: 45- 49.

Karagiannis, E, Michailidis M, Tanou G, Samiotaki M, Karamanoli K, Avramidou E, Ganopoulos I, Madesis P, Molassiotis A (2018). Ethylene -dependent and -independent superficial scald resistance mechanisms in 'Granny Smith' apple fruit. Sci. Rep., $8: 11436$.

Lurie S, Klein J, Ben-Arie R (1989). Physiological changes in diphenylamine-treated 'Granny Smith' apples. Isr. J. Bot. 38:199-207.

Mir NA, Beaudry R (1999). Effect of superficial scald suppression by diphenylamine application on volatile evolution by stored Cortland apple fruit. J. Agr. Food Chem. 47, 7-11.

Mohamed YFY (2017). Effect of some growth stimulants on growth, flowering and postharvest quality of Aster (Symphyotrichum novi-belgiiL.) cv. Purple Monarch. Middle East J. Agric. Res., 6(2): 264-273.

Moran R (1982). Formula for determination of chlorophyll pigment extracted with $\mathrm{N}, \mathrm{N}$ diethyl formamide. Plant Phys., 69: .1376-1381

Mørk EK, Kristiansen K, LyngsJørgensen HJ, Sundelin T (2011). First Report of Golovinomyces cichoracearum as the Causal Agent of Powdery 
Mildew on Symphyotrichum novi-belgii (Synonym Aster novi-belgii) in Denmark. J. Plant Dis., 95 (2) $: 228$.

Naglaa M, Khattab M, El-Shennawy O, Mostafa M (2011). Effect of nitrogen and some antioxidants on tuberose production, Alex. J. Agric. Res., 56: 4963.

Purvis AC, Gegogeine JW (2003). Diphenylamine inhibits respiration of Green Bell peppers. J. Am. Soc. Hortic. Sci., 128: 924-929.

Rida M (2019). Prolong the vase life of flower spike of Aster New York (Symphyotrichum novi-belgii L.) cv. white casablanca by Diphenylamine. Scientific J. of Agri. Sci.1 (2): 10-19.

Snedecor GW, Cochran W (1989). Statistical Methods, $8^{\text {th }}$ ed. Edition, Iowa State University Press.
Stino RG, Mohsen AT, Maksouds MA, Abd ElMigeed MM, Gomaa AM, Ibrahim AY (2009). Bioorganic fertilization and its Impact on Apricot young trees in newly reclaimed soil. AmericanEurasion. J. Agric. Environ. Sci., 6(1): 62-69.

Wellburn AR (1994). The spectral determination of chlorophylls $a$ and $b$, as well as total carotenoids, using various solvents with spectrophotometers of different resolution. J. Plant Physiol. 144(3): $307-$ 313.

Zidan E (1962). Evaluation of some tomato lives of tomato in record to leaf area and leaf efficiency and relation of partial to early and total yield, fruit size, soluble solids, leaf rolling and blossom - end rot ph. D. thesis, Cornel Univ. Itacha N.Y., U.S.A.

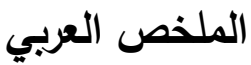

تأثير المستويات المختلفة وطرق إضافة الداي فينيل امين على انتاج وجودة ازهار نباتات الاستر

$$
\begin{aligned}
& \text { نجلاء محمد مصطفى } \\
& \text { فرع بحوث نباتات الزينة بانطونيادس - الإسكندرية - قسم بحوث نباتات الزينة وتتسيق الحدائق - معهد بحوث البساتين - مركز البحوث } \\
& \text { الزراعية - جمهورية مصر العربية. }
\end{aligned}
$$

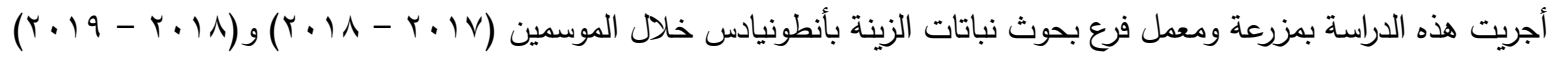

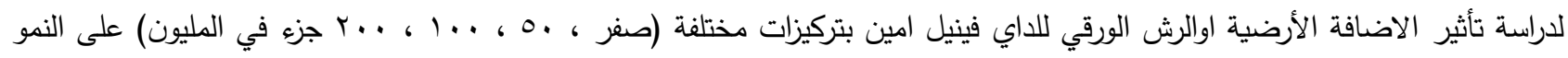

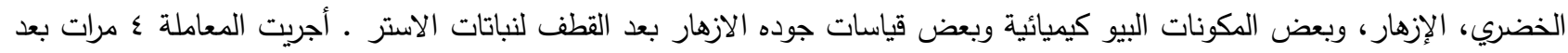

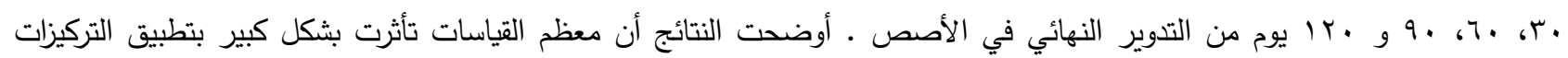

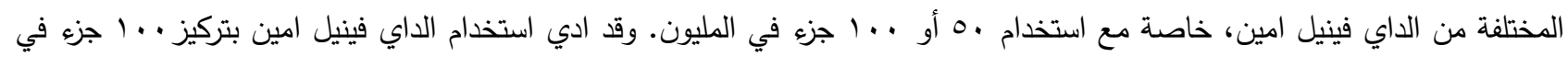

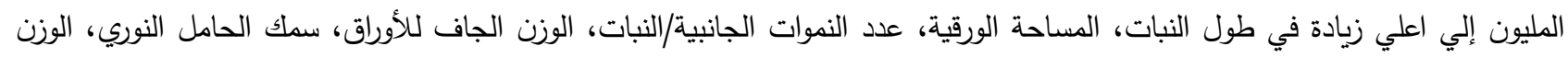

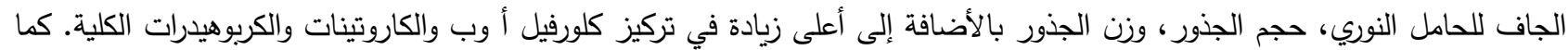

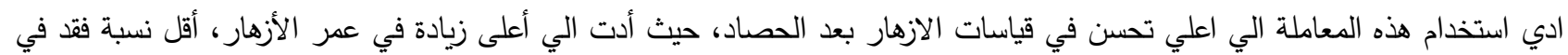

$$
\begin{aligned}
& \text { الوزن الخضري، أعلى كميه ماء ممتصه، أعلي نسبة تقتح للزهيرات. }
\end{aligned}
$$

